\title{
The capitalist crisis and its implications for the Turkish economy
}

\begin{abstract}
This is not the first crisis of capitalism. However, it is the deepest since the Great Depression of 1929-1933. It emerged first in the financial sector in the USA, causing a total collapse of the financial system and a credit crunch. This turned into a real crisis by inducing a recession; consequently, economic growth decreased whilst unemployment rates, bankruptcies and financial losses reached a critical stage all over the world. The official view states that, with the precautions taken after the 2001 crises in the banking sector, the 2008-09 financial crisis will not affect Turkey severely, but the engines of growth for both local and foreign markets in the country, such as textiles and the automotive and construction industries are badly affected. The Turkish economy has been hit by the crisis starting in these sectors and its related effects are becoming heavier each day. The measures taken by the government thus far are aimed at making the working class and the unemployed pay the bill for the crisis, as always.
\end{abstract}

Keywords: financial crisis, recovery, speculative bubbles, budget cuts, recession, anti-crisis measurements

\section{Introduction: crises in historical process and the 2008 crisis}

When we look at historic crises of capitalism as a mode of production, we can see that the 2008 financial crisis and subsequent recession is not the first crisis of capitalism. The first crisis appeared in England, the centre of capitalism, between 1845-1847 and spread all over Europe within ten years. Later, another came into existence in the USA in 1873 and continued in intervals until 1898 (Bowers, 1931; Eyck, 1950).

However, the deepest crisis of capitalism in history started in 1929 and lasted until 1933 - The Great Depression. Like the others, this crisis also first broke out in the financial sector. It emerged with the collapse of the Wall Street Stock Exchange on 29 October 1929, recorded in history as 'Black Tuesday', and followed by the collapse of a range of banks. In the economic sector, capital goods industries, construction and agriculture were seriously affected by the crisis and the USA lost 30 per cent of its GDP, the unemployment rate increased from $3 \%$ to $25 \%$ and consumer prices decreased by $27 \%$ in this period. As a result, incomes, profits, prices and wages decreased severely in all sectors ranging from agriculture to industry (Stiglitz, 2000: 6; Global Danske Bank, 2009). This period, in which the volume of international trade shrunk by between fifty and seventy per cent, caused all capitalist countries to go through a spiral of crises. 
Before the 2008 crisis, in the period between 1970 and 2001, several crises existed on a regional basis. Nevertheless, it was possible to overcome these in a rather short time. The methods that capitalism has used up to now to resolve such crises have been: direct government interventions; Keynesian fiscal and monetary policies; IMF-supported neo-liberal policies and corrective wars, for example, the Second World War.

The distinctive features of the 2008 crisis were the derivative instruments whose value originates from other paper of value and derivative markets that are both widespread and particularly deterministic in the emergence of the crisis. Today, the total value of these instruments is hundred times more than the total assets of all banks: according to ISDA, the total value of derivative instruments is more than $\$ 600 \mathrm{tn}$. The total value of instruments not officially listed as risky, i.e. those traded under the counter and opaquely, is above $\$ 50 \mathrm{tn}$. In the first half of 2008, interest rate swaps reached $\$ 465$ tn (a $22 \%$ increase with respect to the previous year); credit default swaps (CDS) $\$ 55$ tn and private sector stock/security swaps \$12tn (ISDA, 2009). In comparison, global GNP is only one-tenth of this amount, roughly $\$ 60 \mathrm{tn}$.

This crisis emerged in the USA, the centre of the accumulation of capital and the whole financial sector, where the heart of the metropolis collapsed, the credit mechanism was paralysed and financial crisis spread across the world in only three weeks. This led the impact of the crisis on the capitalist world to be both more intense and more rapid. The financial crisis turned into a real crisis by leading to a recession and consequently a decline in economic growth, whilst the unemployment rate, bankruptcies and financial losses reached a critical level.

Moreover, there is still no clue as to when the crises will be overcome, despite trillions of US dollars having been spent on rescue packages since the middle of 2008. In fact, the Asian crisis of 1997-98 was resolved with the financial assistance of just $\$ 100$ bn. Furthermore, nearly three years on, the current crisis remains deep whereas previous financial crises have been mostly resolved within 6-12 months.

It is estimated that, in the USA alone, the losses that the crises have caused will reach $\$ 6 \mathrm{tn}$, in terms of the decrease in the value of real estate; \$3-4tn in terms of the losses of the banking sector; while stock exchange and securities losses are likely to total \$10-12tn (Thomson, 2008). The national income of the USA is \$14-15tn. Other centres of capitalism, the UK in particular, have also faced such major losses. According to the Asian Development Bank, the worldwide loss in the financial sector alone exposed by the 2008 crisis is around $\$ 50$ tn.

\section{How did the crisis emerge?}

It will be helpful to explain the crisis by detailing the dynamics that led to its emergence. The crisis began with the creation of the real estate bubble in financial markets during the 2000s. The incoming recession threat in March 2001 to the American economy, and the loss of confidence in consumers and investors in it after the 11 September attacks, led the Federal Reserve to decrease short-term interest rates on the basis of concern that there may be a financial collapse. Central interest rates were decreased from $6.5 \%$ to $1.75 \%$ in an economy that was revitalised by the interest rate reductions; high profits made between 2003-2006 further increased excessive liquidity worldwide. 
In other words, the fear of recession led the Fed to decrease interest rates in the 2001-2006 period, and this created the opportunity for low-cost/easy borrowing at low rates of interest. This paved the way for a boom in consumer credit.

The needs for housing of Americans with low incomes had increased the appetite of the financial system over a long period. At the same time, it was apparent that this group was too risky, for the people in it either did not have enough funds to make down payments nor did they have credit histories - or else had bad ones. Their income registries were also inadequate to obtain information about them. If mortgage loans were to be supplied to this so-called sub-prime group, their structure had to be different from standardised loans and this was what happened; people who applied for these loans filed rather overblown statements with the banks, and the banks turned a blind eye.

These kinds of loan are more risky because they can be repaid only if the prices of the mortgaged properties increase. Therefore, such mortgages were designed specifically and were exchanged with specially-designed securities, while the risks were sought to be dissipated via some old and new derivative instruments. In this bubble, the total amount of such mortgages reached \$6tn in the 2005-2007 period. One-quarter of these mortgages was made up of loans to riskier sub-prime and Alt A groups, the share of which grew 800 per cent in one year (Zigas et al, 2002).

The mortgage bubble waned when house prices started to fall at the end of 2006, a fall which accelerated in 2007 and 2008 (Lenetis, 2007; Gorton, 2008: 20). The reason for the fall in prices was the rapid increase in interest rates during the same period. The interest rate, which had been $2.25 \%$ in 2004, increased to $5.25 \%$ in December 2006. In fact, it had been only $1.75 \%$ in 2001 (Fed rate). Interest rates were also increased to prevent inflation and consequently the rapid loss in value of the US dollar. This rapid increase in interest rates triggered a credit crunch, because most sub-prime debtors could not manage to make interest payments during 2006-2007: the majority of subprime mortgages had been designed as 2-28 or 3-27 hybrid schemes, meaning that interest rates were fixed for the first 2 or 3 years but the rest was floating (Gorton, 2008: 4).

In other words, when the summer of 2007 approached, millions of Americans with low incomes who had taken sub-prime mortgages were in such a state that they could not pay back mortgage instalments when interest rates increased after the second and third years of the mortgage. As a result of these, the banks re-possessed the houses and rushed to turn these into cash by disposing of them. This situation caused a drastic decrease in house prices and in the mortgageable values of the houses, too. Falling property prices meant that debtors could not carry out re-financing. First the homeowners, then the institutions who created the securities over the mortgages and sold them, then the traders, then the banks who kept these securities as assets, and finally the risk insurers went through a situation in which they could not pay back their debts to each other, heading for a credit crunch. The trend towards cash was increased and interest rates rose further. The precise location of the risk could not be known, so financial intermediaries stopped trading. The financial system was locked up in a domino effect and collapsed. The financial crisis spread all over the world in only three weeks, as well as to the economic sectors of the economy in a short space of time, and has continued to deepen. 
Briefly, at the superficial level, there were two main sources of the problem: the fall in house prices; and the spread of toxic credit issued on the basis of those mortgages across the whole financial system without any controls. The distribution of $60 \%$ of these toxic instruments to other centres of capitalism and world markets spread the crisis across the world.

\section{How should the crisis be analysed?}

The so-called financial crisis is indeed a symptom, of the sick mode of production of capitalism. In other words, the underlying disease is capitalism: an economic system that weaves consistent and destructive conflicts into its production and distribution of goods and services.

To make the capitalist economy work, there is a need for co-operation between employer and employees. However, the interests of these two classes are in such conflict that the economy is dragged periodically into crises. Capitalism does not only lead to conflicts between employees and employer, but also to unlimited and endless struggles between profit-maximising employers that we call competition. It too erupts into conflicts and crises.

Under capitalism, goods are produced for profit, not for the satisfaction of human need. Therefore, whereas plenty of things necessary for human beings are not produced in sufficient quantity, such as cancer research, AIDS research, and art activities, for example (Stiglitz, 2000: 76), many things that people do not really need but which are profitable are produced excessively, including weapons, jewellery, etc. The competitive structure of capitalist production leads also to anarchy in production. Market anarchy may be added to that, in the case of expanded production: the production and marketing process must expand constantly in order to realise the surplus value to make profit and then initiate new investment. The surplus value is the sole resource of profit, while profit is the main stimulus for the new investments required to sustain expanded capitalist production, thereby the accumulation of capital. Nevertheless, this progress increases the density of capital, or the organic composition of capital, which destabilises the production-consumption balance and leads to excess production and, as a result, a deficient consumption leading to the problem of profit realisation (Marx, 1863: 505-522; Taylor, 1996: Ch. 11). This is repeated in long- or short-term boom-bust cycles, following which crisis emerges.

After 150 years of modern capitalism, three types of boom-bust cycles can be roughly identified. The first type of these cycles is relatively nationwide or regional short-term cycles that emerge over approximately 7-10 years (for instance, the 1974/1975, 1980/1982 and 2001/2002 crises).

The second type of cycle is called Kondratieff Waves in the literature. These cycles are global, long-term cycles and appear approximately once every 50-60 years. According to Kondratieff, these cycles have four phases: spring (refreshment); summer (recession); autumn (plateau); and winter (depression) (Kondratieff, 1926). The cycle is completed over 25-30 years of refreshment, 25-30 years of recession, and then crisis. In this context, it can be suggested that today's long-term global cycle started in 1945 with growth, but this reversed in 1970-73, since which time a longer than normal autumn period started. The reason why this is lasting longer than normal is state inter- 
ventions which have lengthened the existence of crisis. These interventions postponed collapse, but also deepened it.

As a third type, longer-term cycles can be stated as a result of the geographical change of imperial hegemony. Hegemonic relations are shaped in the concept of regional, centre, semi-centre and peripheral countries in accordance with their importance in the period of accumulation of capital. Thus, in hierarchical order, it is possible that a sub-country or region can be hegemonic. In fact, the hegemonic centre of capitalist accumulation shifted to Great Britain in the $18^{\text {th }}$ century, while the USA became a rival to Great Britain's hegemonic power in 1870, after which the USA finally became unrivalled after 1945. Hegemonic power status is characterised according to relative productivity vis-à-vis a country's rivals and to technological dynamism. In a period of economic decline, production centres start to move to other regions of the world, the tendency of financialisation increases and, subsequently, new investment tends to shift towards speculative activities in the economies of imperialist countries. This pattern may be observed in almost all hegemonic countries. In fact, financialisation has accelerated in the US economy since the 1970s.

In an increasingly financialised capitalist regime, the economy is characterised mainly in asset bubbles (Bellofiore and Halevi, 2009). The leadership role of US capitalism in the progress of global financialisation depends, in turn, on the power of the US economy to create such bubbles; on its role as the catalyst for effective world demand since the 1980s; and on the US dollar becoming the reserve money. However, such a financialised economy is not able to create rapid and sustainable growth. Actually, financialisation has caused big bubbles to emerge periodically that surface in a recession.

The period starting in the 1970s has been one in which the conflict between labour and capital has increased. Capitalists accelerated their attacks on the working class and have put pressure on real wages since the 1980s. During this period, capitalists have succeeded in depressing the real wages of their workers by employing cheap foreign labour, using more women in production and importing low-waged immigrant workers to the country, hence increasing surplus value. In the 1990s, the significantly enhanced worker productivity increased relative surplus value and, therefore, profits.

As a result of these developments, corporate profits have increased while workers' real wages have been at a standstill. However, their wages were insufficient to buy the things that they produced. So, the production-consumption balance is disrupted. For instance, in the USA, the share of wages and salaries in GNP decreased from $53.5 \%$ in 1970 to $45.5 \%$ in 1995 . This meant that the share of workers dropped about eight percentage points in 25 years. The share of wages and salaries rose a little (to $49.8 \%$ ) between 1995-2000, before falling back again by 2005 to $45 \%$. Per hour, wages were \$9.0 in 1972; decreasing to \$8.0 in 2006 (Foster and Magdoff, 2008: 7).

Thus, starting in the 1970 s, instability has emerged in excess production or a lack of consumption, leading to an economy running into recession. However, in those years US capitalism found a way to postpone the approaching recession: consumer loans. On the one hand, employers put pressure on workers' wages. On the other, they managed to sell products to workers by offering them loans. Most companies invested their huge profits in new securities which were supported by the facilities provided for consumer 
loans for houses and automobile purchases, and credit cards. In brief, in the 2000s, impending recession was postponed thanks to the financial system and to sub-prime mortgages.

In this way, the holders of such securities managed to sequester some of the monthly repayments that workers made in respect of those credits. In fact, they multiplied the profits they made by lowering the wages of workers with the serious interest they gained by giving loans to workers. So, capital obtained both profit and interest.

The postponement of the crisis since the 1970s via consumer loans was an advance preparation for the crisis we are now suffering. The boom in consumer loans in the 1980s and 1990s, and the financial de-regulations by, in particular, the Bush administration since 2000 was responsible for provoking the developments of today in terms of profit maximisation and corruption (stock market bubbles and stock exchange bubbles, etc.). Millions of Americans fell under an unsustainable debt burden. By 2006, so-called sub-prime debtors - the most stranded, most risky ones - could not make their re-payments.

The harsh levels of competition between capitalists also contributed to these crises. On the one hand, competition saw the gaining of a portion of the consumer loan cake among the banks; on the other, banks were creating the new financial instruments (CDSs, CDOs), with no secured basis, to fund the loans they offered to consumers and started to borrow huge amounts of money from the financial institutions. So, the relentless struggle for profit among financial enterprises, in line with bitter competition and, consequently, countless risk-taking, deepened the crises (Borio, 2008: 10-11). Creditors from the USA sold these so-called toxic derivatives all over on a retail basis, and so the whole world was drawn into the boiling pot.

Thus, in short, US capitalism, via consumer loans as sub-prime mortgages, was hoping:

- to increase total demand by increasing consumption and production expenditures for housing

- postpone the impending recession

- overcome the profit squeeze in the economic sector

- satisfy the excessive desire for profits of the giant, autonomous financial capital houses.

\section{8 crisis and Turkey: crisis strikes Turkey}

Turkish capitalists have been warning that the crisis is especially serious, but the Prime Minister of Turkey and government spokesmen have stated that the crisis was a passing one, such that the Turkish economy would not be affected by it. In their view, with the precautions taken after the 2001 crises in the banking sector, this sector had been put on a secure footing and, hence, the 2008 financial crisis would indeed not affect Turkey severely.

An important mistake in these statements was the belief that the crisis would strike Turkey through the financial sector. In fact, none of the crisis analysts claimed that the crisis would strike Turkey directly through the banking sector or the aforementioned 
toxic instruments. On the contrary, there was a consensus that the crisis would affect Turkey in the real, production sector of the economy.

On the other hand, an IMF research study published in March 2009 claims that none of the banks in the world, including in Turkey, were safe (Maechler and Ong, 2009: 12-23). This report revealed that even the world's most powerful banks could not survive in the case of a credit crunch. Even if the banking sector in central, eastern and south-eastern Europe countries, including Turkey, was able to dodge the direct effects of sub-prime mortgage and toxic instruments (as they do not have substantial amounts of such derivatives in their structures), they are still under serious risk because they are integrated within the international financial system and have been taken over by banks from European and other capitalist countries.

One-third of the receivables of badly-affected western banks in Turkey are due directly from other banks, while the rest is from the economic sector. However, the economic sector uses the guarantees of the banking system when obtaining such loans, so the banks in Turkey as well as the economic sector are under major risk. These effects can happen through the channels of credit lines, foreign trade, portfolio investments and expectations. Again, according to the report, the danger is a growing one because the creditor banks are calling in their credits (Maechler and Ong, 2009: 20-32).

Another subject agreed upon is that the crisis has only recently started to affect Turkey and that the real effects will be seen from 2009 onwards. In fact, the news coming especially from sectors that are engines of growth for both local and foreign markets, such as textiles, the automotive industry and construction, are not cheering. As will be detailed below, the Turkish economy is being struck by the crisis starting in these sectors, and the related effects are becoming heavier with each day.

An under-developed and semi-colonial capitalist economy, the soft spots of the Turkish economy are, respectively:

- a relatively high level of current account deficit

- high foreign debts in both the private and public sectors

- a high level of unemployment and under-employment.

First of all, there is a relatively high level of current account deficit in Turkey. Between 2002 and 2009, this deficit (the foreign exchange gap) multiplied 100 times: it was $\$ 0.6$ bn in 2002 , but reached $\$ 38.2$ bn in 2007 . At the end of 2008 , the deficit was $\$ 41.4 \mathrm{bn}$. The main factor in the current deficit is the deficit in foreign trade (importsexports). This stood at $\$ 54.0 \mathrm{bn}$ in 2006 (24.8\% up on the previous year); $\$ 62.8 \mathrm{bn}$ in 2007 (16.2\% up on 2006); \$69.8bn in 2008 (11.2\% up on 2007; and made up of \$201.8bn of exports and \$132.0bn of imports) (CBT, 27 February 2009).

The global recession has caused a drastic decrease in Turkish exports. In fact, exports in February 2009 were down $35 \%$ compared to the figure in the previous February. The decrease was $28 \%$ in January 2009 and $25 \%$ in December 2008. According to CBT's annual and monthly balance of payment statistics, the average fall in exports in February 2009 was in excess of $38 \%$, but it reached a peak of $55 \%$ in the motive export sector, for example in the automotives and automotive parts industries. Moreover, the global recession has also caused a decrease in tourist incomes in related sectors of the economy. 
A current deficit can be financed through foreign direct investment (FDI), hot money, foreign debts and the foreign currency reserves held by the Central Bank. Firstly, a severe decrease in foreign direct investment has been observed since 2007, such that the figure was \$20.1bn in 2006 (101.2\% up on the previous year) and \$22bn in 2007 (a $10.1 \%$ increase). In 2008, however, FDI was only $\$ 17.7$ bn (a $19.5 \%$ decrease on 2007).

Secondly, the amount of short-term foreign investments (portfolio investments), referred to as hot money, which was the most crucial financial stimulus behind the rather higher growth of the Turkish economy since 2002, declined drastically. This hit a level of about $\$ 107$ bn in 2007, but was down to \$48.9bn in the August 2008 - January 2009 period ( $45 \%$ of its previous level) when the crisis intensified.

Thirdly, the current deficit is increasingly financed by foreign debt. The share of foreign debt in current deficit financing was only $12 \%$ in 2006, but it increased to $56 \%$ in 2007 and to $62 \%$ in September 2008 (CBT, 2008: 20). At the third quarter of 2009 , Turkey's gross total foreign debt is $\$ 274 \mathrm{bn}$. What is worrying is that almost twothirds of foreign debt $(\$ 176 \mathrm{bn})$ belongs to the private sector of the economy. The foreign currency deficit of Koç Holdings Group alone was around \$3.3bn (ISE, 31 December 2008). Private sector foreign debt was only $\$ 43$ bn in 2002 , but rose to $\$ 118.5$ bn in 2006 , to $\$ 158.2 \mathrm{bn}$ in 2007 and to $\$ 196.2 \mathrm{bn}$ at the third quarter of 2008 , indicating that the foreign debt of the private sector in Turkey increased by 3.5 times in 5.5 years (UT, 2009). It had dropped to $\$ 176 \mathrm{bn}$ at the end of 2009 , but this indicates that the Turkish economy may face a foreign debt crisis in the near future. That is why major capitalist groups are forcing the government to sign a new stand-by agreement with the International Monetary Fund (IMF).

The effects of the crisis on other indicators are also apparent. The rate of economic growth slowed down at first and then turned negative. Growth was $6.9 \%$ in 2006, but decreased to $4.7 \%$ in $2007,2.8 \%$ in the second quarter of $2008,1.2 \%$ in the third quarter and to $-6.2 \%$ in the last quarter (TurkStat, 31 March 2009). The growth rate was expected to be $-6.0 \%$ in 2009 .

The number of companies which are shut down after the crisis rapidly increases, just as there is a real delay in setting up new firms. For instance, the number of corporate bankruptcies exceeded 37000 (58\% up between 2007 and 2008) (TurkStat, 23 January 2009).

The industry production index fell back in each of the last seven months of 2008, except for September: it fell by $1.8 \%$ in June 2008, $0.3 \%$ in July, $8.4 \%$ in August, $2.7 \%$ in October, $0.5 \%$ in November and $14.9 \%$ in December (TurkStat, 9 March 2009).

Capacity usage rates are also falling in industry. Capacity usage was $81.7 \%$ in December 2006, but decreased to $81.2 \%$ in December 2007, and to $64.7 \%$ in December 2008. Industrial capacity usage rates are, in fact, suffering the highest rates of fall in the last seventeen years. For the first time in this period, a drop of over $16 \%$ occurred. Such a fall was not witnessed even in the 1994 and 2001 crises, or in the 1999 earthquake (TurkStat). In November 2009, capacity usage was only $70.7 \%$ (10 \% down on January 2008) (TurkStat). 
Decreases in growth, capacity usage and in the industrial production index, as well as increases in the numbers of companies which have been shut down, has led to a sharp rise in the unemployment rate. According to the data of TUIK, the unemployment rate, which was $9.6 \%$ in November 2006 and $10.1 \%$ in November 2007, increased to $12.3 \%$ in November 2008, 13.6 \% in December 2008 and $15.5 \%$ in January 2009. For 2009 as a whole, it was 14.6\% (TurkStat, 15 April 2009; TurkStat, 16 February 2009; TurkStat, 15 February 2008). Nevertheless, the actual unemployment rate is far higher than these figures indicate: the labour participation rate is just $44 \%$ (as opposed to $66 \%$ in OECD countries) (TurkStat), since the official figures exclude people who have not applied to the employment agency and those who have stopped looking for work, while seasonal and part-time workers are simply not encompassed by them.

Other indicators of economic recession are also apparent. For example, there has been a sharp increase in the amount of bounced cheques and bonds during the crisis: from a value of YTL $0.9 \mathrm{bn}$ in 2003; YTL 1.7bn in 2004; YTL 2.8bn in 2005; YTL $4.1 \mathrm{bn}$ in 2006; and YTL 5.7bn in 2007, it rose to TL 6.8bn in 2008 (19.3\% up on the 2007 figure) (CBT, 2008b).

Looking at the indices of the expectations of consumers and manufacturers, it can be seen that there has been an apparent deterioration since 2007. The CBT-TurkStat Consumer Trust Index was 91.8 points in January 2007, but this decreased to 92.1 points in January 2008 and to 71.6 points in January 2009. Similarly, according to CBT statistics, the Real Sector Trust Index was 111.3 points in January 2007 before decreasing to 104.2 points in January 2008 and to 59.4 points (i.e. it had almost halved) in January 2009.

Economic activities have further deteriorated in sectors that are regarded as the engine room of the Turkish economy. For instance, according to CBT statistics, in the construction sector a serious recession is being experienced: there was a fall of approximately $10 \%$ in the number of flats built in the first six months of 2008 .

There is also a serious recession in the automotive sector. In January 2009 compared to January 2008, the production of automobiles decreased by $61 \%$, trade vehicles by $71 \%$ and tractors by $55 \%$. Consequently, vehicle sales in January 2009 compared to January 2008 dropped sharply, with automobile sales falling by $29 \%$ and light commercial vehicle sales by $50 \%$ (AMA, 2009). When exports are considered, it may be seen that the exports of vehicles and parts made up $19.4 \%$ of total Turkish exports in 2008. In the same year, however, the speed of growth of automobile exports was negative for the first time. When it is considered that one-third of the taxes collected in Turkey come from the automotive and parts industry (VAT, SCT, MVT, IT and CT), it is apparent that tax revenues will have decreased.

When the values of the National 100 Index are considered, it is clear that IMKB (Istanbul Stock Exchange) has seen the lowest level of the last 52 months. The Index, which was 54.214 on 30 November 2007, fell to 21.966 on 21 November 2008 (ISE, Daily Bulletins). In this period, the share of foreigners in IMKB fell from $72.3 \%$ on 2 January 2008 to $70.7 \%$ on 11 August 2008 and to $66.4 \%$ on 13 February 2009 (CRA, 2009). The US dollar reached its highest rate of the last 28 months against the Turkish Lira (TL), while the latter lost $44 \%$ of its value compared to the beginning of the year. 
Total gross public debt stock was YTL 257bn in 2002. However, it increased to TL $356 \mathrm{bn}$ in 2007 and to TL 434bn in the second quarter of 2009 (UT, 2010). On the other hand, the giant increase in consumer loans and credit card debt shows that the risks related to debt in the economy are not limited to the public or corporate sectors. With increasing unemployment and poverty, people who earn income from labour are also under a major risk of default. In fact, these debts, which were YTL 5.8bn on 4 May 2001, had bounced to TL 114.2 bn by the end of January 2009, according to CBT statistics.

One of the most significant effects of the recession is the reduction in state revenues, in particular taxation. In fact, both tax revenues and social security contributions, like SSK and Bağ-Kur premiums, have fallen. For example, total tax revenues, which form at least $85 \%$ of total monthly public revenues, fell from TL $14.2 \mathrm{bn}$ to TL $13.8 \mathrm{bn}$ in January 2009 compared to January of the previous year $(2.4 \%$ down $)$. In the same period, value added tax (VAT) revenues fell from TL $4.2 \mathrm{bn}$ to TL $3.4 \mathrm{bn}$ ( $18 \%$ down), and special consumption tax (SCT) fell from TL $3.4 \mathrm{bn}$ to TL $3.2 \mathrm{bn}$ (5.3\% down) (BFC, 2009). These revenue decreases in indirect taxes indicate the deep effects of the recession on public finance. In total, whereas it was planned to collect TL $202 \mathrm{bn}$ in tax revenues in 2009; realistically, it is expected to be a maximum of TL $163 \mathrm{bn}$.

In the meantime, when we consider the high level of the Producer Price Index (PPI) and the Consumer Price Index (CPI), which stand respectively at $7.9 \%$ and $9.5 \%$, the fall in VAT and SCT revenues is actually higher. What is worse, public expenditure has increased due to the local elections held in March 2009, causing further budget deficits.

Despite all these factors, the 2009 State Budget was prepared as if there was no crisis at all. For instance, the exchange rate of the US dollar to the Turkish Lira was estimated to be $\$ 1=\mathrm{TL} 1.41$; it is also estimated that the increase in privatisation revenues will be $42 \%$, the increase in tax revenues will be $16 \%$ and, finally, the growth rate will be $4 \%$.

In contrast, according to the Ministry of Finance's General Directorate of Public Accounts statistics, tax revenues in the recession have decreased whereas public expenditures have increased sharply due to the above-mentioned local elections. The budget deficit for 2009 as a whole, which was initially estimated at TL 10.4bn, had already been attained in January and February of that year. It is officially estimated that the budget deficit will be over TL 50bn both in 2009 and 2010. In fact, the stand-by negotiations with the IMF, although officially rejected, predicts that wage and salary increases would be limited; that tax collection rates will be increased; and that social expenditures as regards low-income groups will be limited in 2010; and so on.

\section{Conclusion: Profits are privatised, while losses are socialised}

Capitalism as a system is experiencing its deepest crisis since the Great Depression of 1929-33. Starting with the financial sector being at the core of the current capitalist mode of production, the 2008 crisis has now spread across the whole globe and is affecting the entire world economy. The deepening recession is resulting in a slowdown in manufacturing and trade, losses of income and wages, unemployment, poverty and hunger. 
Capitalism is genetically faulty and this genetic fault has deteriorated, into shortterm cycles causing crises locally or regionally and, at times, into long-term cycles leading to global crises. In this context, it would be wiser to conclude that this crisis, having started in the financial sector, is actually a crisis of the capitalist mode of production itself.

Metropolitan capitalist countries have announced anti-crisis packages of up to $70 \%$ of their GNPs. These packages have included direct nationalisation; the purchase of toxic bank assets; lowering interest rates to almost zero; granting state guarantees to the financial sector; reductions in tax rates; major schemes of public expenditure; stimulating and assisting in company mergers; and, overall, all kinds of direct interventions and monetary and fiscal policies. Capitalist metropolitan governments have, so far, pumped an amount exceeding $\$ 5$ trillion in cash into financial markets worldwide. What is more, at the recent London G20 summit, an additional aid package to an amount of \$1.1 trillion, mostly via the IMF, has also been announced.

In Turkey, the crisis prevention package announced just before the 29 March 2009 local elections includes:

- a reduction in the rate of VAT, from $18 \%$ to $8 \%$, for a temporary period of three months, for new houses over $150 \mathrm{~m}^{2}$

- an extension to the 'short working allowance' scheme, which had commenced earlier, to three months (later, this period was increased to six months and the rate was increased to $50 \%$ )

- decreases in the Special Consumption Tax rate for automobiles by a range of $10-15 \%$, and for durable goods and electronics products to zero per cent

- a decrease in the corporate tax rate for new investments from $20 \%$ to $2 \%$.

As has been seen, the measures taken are, in reality, oriented simply at the destocking of automobiles and durables, and are far from providing relief to the sections of society that have been most affected by the crisis.

More than two years have passed since the beginning of the crisis and, in spite of all the measures and precautions taken, the crisis has not really been resolved, either globally or locally. And the global recovery, which has been presumed to start since April 2009, is still weak and far from being sustainable. Furthermore, the so-called measures are not only ineffective but are also not fair on the working class, the unemployed and the poor.

Some mainstream economists have, since spring 2009, been pointing to the economic 'green shoots' sprouting forth, supposedly heralding an anticipated recovery. More and more optimistic predictions of economic recovery are worldwide. Some other economists, however, have stressed that this is not the end of the crisis, although some economic indicators are pointing to the end of the economic slide. All downturns eventually hit a bottom at which the economy stabilises at a new low level, or from which a recovery takes off. But this is not a normal recession and the recovery, when it comes, will not be a normal recovery. Economists like Roubini and Stiglitz warn that, behind the 'green shoots' and the talk of 'economic recovery', there is, in fact, a return to a new speculative, and probably short-lived, bubble and that we are heading into an extended period of 'economic malaise' and a 'double-dip recession' or, at best, an 
anaemic recovery. Socialists, however, predict that the world is not facing a routine cyclical recession but a deep structural crisis which will probably extend for years.

Some of the underlying factors that seem to be preventing a 'green shoot' recovery from turning into vigorous new growth are as follows:

1. the ongoing financial crisis in the sub-prime mortgage market, due to the decreasing prices of both residential and commercial estate. The financial system is severely damaged, so the credit crunch will not ease quickly

2. corporates' interest payments are falling short of commitments due to weak profitability

3. rising budget deficits and government debt ratios threaten financial stability and may cause a new medium-term crisis

4. China's crisis is deepening and threatening global recovery

5. rising protectionism among leading capitalist countries may cause trade wars

6. financing through consumer credits is no longer an alternative

7. recovery or not, the misery of the working class all over the world will deepen. Unemployment is going to continue to grow, even in a weak recovery. Job creation, moreover, is years away. Cuts in wages, benefits, pensions and health care, and increases in indirect taxes such as VAT and SCT will accelerate, making workers pay for the crisis.

The result of the crisis has been that the people who have dreamed of possessing a house, a private pension scheme, etc. through the financial markets around the world have lost their houses, their jobs and their hopes for future. These people are now paying the price of the crisis, even though they have neither liability nor responsibility regarding the crisis. On the other hand, by means of the rescue operations, profits have been kept by the privatised, while the losses are being socialised.

Countries like Turkey, which are dependent on global capitalism, are paying the bill of the crisis with more unemployment, more poverty and more hunger. However, despite all these, the 2008 crisis has created an opportunity for people to question and to do away with capitalism.

\section{References}

Automotive Manufacturers Association (2009) Monthly Bulletin January, www.osd.org.tr.

Bellofiore, Riccardo and Joseph Halevi (2009) 'A Minsky Moment? The Subprime Crisis and the New Capitalism' in C. Gnos and L. P. Rochon Credit, Money and Macroeconomic Policy: A Post-Keynesian Approach Cheltenham: Edward Elgar).

Borio, C (2008) 'The Financial Turmoil of 2007-? A preliminary assessment and some policy considerations' Bankfor International Settlements (BIS) Working Paper No. 251 March.

Bowers, Claude G (1931) The Tragic Era. The Revolution After Lincoln Blue Ribbon Books: New York.

Central Bank of the Republic of Turkey (2008a) Balance of Payments Report 2008III www.tcmb.gov.tr. 
Central Bank of the Republic of Turkey (2008b) Amount and Number of Protested Bills $2001-2008$ www.tcmb.gov.tr.

Central Bank of the Republic of Turkey (2009) Balance of Payments Detailed Presentation (27.2.2009) www.tcmb.gov.tr.

Central Registry Agency (2009) The Daily Custody Information by Domestic - Foreign Investors Report March www.mkk.com.tr.

Eyck, Erich (1950) Bismarck and the German Empire W.W. Norton \& Company: New York.

Foster, J. Bellamy and F. Magdoff (2008) 'Financial Implosion and Stagnation Back To The Real Economy’ Monthly Review 60, December.

Global Danske Bank (2009) Lessons from the Great Depression 23 February.

Gorton, Gary B (2008) The Subprime Panic NBER Working Paper Series No. 14398.

International Swaps and Derivatives Association Inc (2009) Summaries of Market Results, 2008 Mid-Year 25 March 2009 www.isda.org.

Istanbul Stock Exchange (2008) Financial Tables of Koç Group 31 December, www.imkb.gov.tr.

Istanbul Stock Exchange Daily Bulletins www.imkb.gov.tr.

Kondratieff, Nikolai D (1926) Long Waves in Economic Life (The Kondratieff Theory) www.kwaves.com [accessed on 26 February 2009].

Leventis, A (nd) A Note on the Differences between the OFHEO and S\&P/Case-Shiller House Prices Indexes Office of Federal Housing Enterprise Oversight Working Paper.

Maechler, M. Andrea \& Ong Lainli (2009) Foreign Banks in CESE Countries: In for a Penny, In for a Pound? IMF Working Paper WP/09/54, International Monetary Fund, March.

Marx, Karl (1863) Grundisse (Outlines of the Critique of Political Economy).

Republic of Turkey Ministry of Finance General Directorate of Budget and Fiscal Control (2009) Budget Report - January 2009 www.bumko.gov.tr.

Republic of Turkey Prime Ministry Undersecretariat of Treasury (2010) Public Net Debt Stock 2000Q1 - 2009Q3 www.treasury.gov.tr.

Republic of Turkey Prime Ministry Undersecretariat of Treasury (2009) Gross External Debt Statistics of Turkey 2001 - 2009 www.treasury.gov.tr.

Taylor, Kit Sims (1996) Human Society and the Global Economy. The Instability of Capitalism Chapter 11: Capitalism's Crises and Critics.

The Federal Reserve Board Open Market Operations www.federalreserve.gov/fomc/ fundsrate.htm.

Thomson, William R (2008) 'Global Financial Crisis Worst Since 1930's Depression’ The Market Oracle, Stock-Markets/Credit Crisis 200820 July. 
Turkish Statistical Institute (2008) 'Household Labour Force Survey November 2007' News Bulletin 15 February www.tuik.gov.tr

Turkish Statistical Institute (2009a) 'Established and Liquidated Companies' News Bulletin 23 January www.tuik.gov.tr.

Turkish Statistical Institute (2009b) 'Household Labour Force Survey November 2008' News Bulletin 16 February www.tuik.gov.tr.

Turkish Statistical Institute (2009c) 'Monthly Industrial Production Index January 2009’ News Bulletin 9 March www.tuik.gov.tr.

Turkish Statistical Institute (2009d) 'Gross Domestic Product' News Bulletin 31 March www.tuik.gov.tr.

Turkish Statistical Institute (2009e) 'Household Labour Force Survey January 2009' News Bulletin 15 April www.tuik.gov.tr.

Stiglitz, Joseph A (2000) Economics of the Public Sector (3rd edition) W.W. Norton \& Company.

Zigas, Baary, Carol Parry and Paul Weech (2002) The Rise of Subprime Lending: Causes, Implications and Proposals Fannie Mae Working Paper. 